\title{
URGENSI MANAJEMEN PENDIDIK LEMBAGA PENDIDIKAN ANAK
}

\author{
(Kajian Teoritis dan Implementasinya)
}

Ahmad Salim

(Dosen Prodi PAI STIA Alma Ata Yogyakarta)

\begin{abstract}
Early childhood education has been developing in Indonesia. It needs professional teacher to accomplish the stated goals. To make professional teacher of early childhood education absolutely needs management. In this paper, writer would present the early childhood education teacher management especially in private early childhood education due to it has many problems. Management of teacher in early childhood education is started from identification of teacher qualification and quantity, developing and enrichment the teacher quality by make clear status of teacher, also increasing the teacher revenue/fee. Moreover the leader of early childhood education should manage retiring of the teacher. Writer believes that many steps above could develop quality of early childhood education.
\end{abstract}

Key words: Management, early childhood education, professional teacher,

\section{A. Pendahuluan}

Kesadaran masyarakat akan pentingnya pendidikan pada anak usia dini dewasa ini dirasakan mengalami peningkatan cukup berarti. Keadaan ini paling tidak dibuktikan dengan dua kecenderungan yang terjadi pada masyarakat kita yaitu; meningkatnya jumlah orang tua yang memasukkan anaknya ke lembaga pendidikan anak serta diikuti juga dengan meningkatnya jumlah lembaga pendidikan yang didirikan baik oleh pemerintah ataupun swasta. Sehingga praktis hampir semua daerah di Indonesia telah terdapat lembaga pendidikan anak dengan berbagai jenis, bentuk dan keadaanya. Kharakteristik lembaga pendidikan anak yang didirikan akan sangat dipengaruhi oleh lembaga pendiri dan letak suatu daerah, misalnya daerah perkotaan banyak didirikan tempat layanan penitipan dan pengasuhan anak sedangkan daerah pedesaan banyak didirikan lembaga pendidikan anak yang tidak melayani sampai pada penitipan. Keadaan di atas sejalan dengan apa yang dimuat pada web kemendikbud yang mengungkap tentang 
perkembangan angka partisipasi kasar siswa pendidikan anak usia dini sejak tahun 2009 telah mencapai 15,3 juta atau 53,3\%.

Kecenderungan meningkatnya kesadaran masyarakat terhadap pendidikan anaknya pada usia dini layak kita berikan apresiasi. Sebab, hal ini selain dapat meningkatkan angka partisipasi kasar pendidikan nasional juga dapat meningkatkan kualitas sumber daya manusia Indonesia pada masa yang akan datang. Tidak bisa dipungkiri bahwa penyiapan sumber daya manusia berkualitas mutlak dimulai dari pendidikan anak pada usia dini. Hal senada dikatakan oleh $\mathrm{E}$ Khaton (2012;7) dan Hidayat (2012;7) yang menyatakan bahwa pendidikan terutama agama perlu sekali dilakukan sejak usia dini dengan pendidikan yang benar yaitu pendidikan yang menyentuh ranah kehidupan nyata agar dihasilkan insan-insan berkualitas di masa akan datang. Dengan bahasa sederhana dapat dikatakan bahwa jika sebuah bangsa atau negara ingin memiliki sumber daya manusia berkualitas maka harus disiapkan pendidikanya sejak usia dini.

Salah satu komponen yang dapat menentukan berkualitas tidaknya output siswa adalah tenaga pendidik (guru). Sampai detik ini tidak ada satu pakar pun yang meragukan akan pentinya peran guru dalam menghantarkan output yang berkualitas pendidikan pada semua level, level pendidikan tinggi, pendidikan menengah apalagi pada level pendidikan dasar atau pendidikan anak usia dini. Peran penting guru sebagai agent of instruction tidak hanya dapat dilihat pada pembelajaran yang berlangsung di dalam kelas. Peran yang lebih luas dapat dilihat secara jelas pada semua aspek pembelajaran baik pada pembelajaran di dalam kelas, peran administrator, supervisor, manager dan lain sebagainya.

Pada level pendidikan anak usia dini peran dominan guru lebih terfokus kepada kemampuan guru untuk adjust terhadap perkembangan siswa pada anak usia dini pada berbagai aspek baik kognitif, afektif, maupun psikomotorinya. Keadaan tersebut memberikan pengertian kepada kita bahwa seorang pendidik/guru pada lembaga pendidikan anak membutuhkan kemampuan professional sesuai dengan bidangnya agar mampu memenuhi tuntutan perlembangan zaman dan perkembangan anak didiknya.

Anggapan bahwa menjadi guru pada pendidikan dasar adalah sangat gampang karena materi pembelajaranya masih sangat dasar adalah sebuah anggapan yang sangat keliru. Justru menjadi guru pada pendidikan dasar adalah sebuah pekerjaan yang sangat berat, sebab 
selain materi yang harus dikuasai pekerjaan pada level ini sangat menuntut pemahaman komprehensif guru terhadap perkembangan fisik dan psikologis peserta didiknya. Konsekwensinya guru harus "maha tahu" pada semua materi serta seluk beluk yang melingkupinya seperti : pada metode, strategi, media, alat dan lain sebaginya. Guru harus bisa menjadi pengganti orang tua peserta didik, yaitu harus mau mengenal, mengetahui dan memahami peserta didiknya pada semua aspek yang dimiliki oleh peserta didik. Langkah-langkah mengenal, mengetahui dan memahami tersebut bila diterapkan secara optimal tentu akan sangat berpengaruh pada pencapaian perkembangan peserta didik secara optimal pula.

Untuk meningkatkan kompetensi guru lembaga pendidikan anak sehingga menjadi guru professional diperlukan sebuah manajemen. Sebagaimana tertera pada UU Sikdiknas No 20 Tahun 2003 pasal 57 ayat I yang berbunyi bahwa pengelolaan lembaga pendidikan pada semua level termasuk pada usia dini harus dilakukan berdasarkan prinsip manajemen berbasis sekolah. Tulisan ini berusaha mengungkap manajemen professional guru lembaga pendidikan anak milik masyarakat (swasta) dari tinjuaan teoritis dan implementasinya. Ini dilakukan dengan asumsi bahwa lembaga pendidikan anak swasta jumlahnya lebih besar serta manajemen lembaganya masih banyak mengalami kendala/masalah.

\section{B. Konsep Manajemen Pendidikan}

Manajemen pendidikan merupakan kajian yang berakar dari manajemen ekonomi/bisnis, walaupun demikian dalam perkembanganya, manajemen juga diperlukan dalam upaya-upaya nirlaba seperti sekolah, lembaga keagamaan dan lembaga sosial lainya (Satyagraha, 2005). Manajemen menurut Coombs, Sergiovani, Thurston dalam Sukirman $(2000 ; 14)$ adalah process of working with and through others to accomplish organizational goals efficiently. Kemudian menurut Terry dalam Purwanto $(2005 ; 7)$ manajemen adalah distinct process consisting of planning, organizing, actuating and controlling performed to determine and accomplish stated objectives by use of human being and others recourses.

Sedangkan menurut Pidarta (1988; 22) dan Bafadal (2000; 5) manajemen pendidikan adalah aktivitas memadukan sumber-sumber pendidikan agar terpusat dalam mencapai tujuan pendidikan yang 
telah ditetapkan. Soepardi $(1998 ; 112)$ memberikan pendapat tentang manajemen pendidikan sebagai rangkaian kegiatan pendidikan yang memanfaatkan seluruh fasilitas, baik manusia maupun bukan untuk mencapai suatu tujuan pendidikan yang telah ditentukan sebelumnya. Para ahli manajemen pendidikan di atas memberikan pengertian yang homogen tentang manajemen pendidikan yaitu sebuah cabang ilmu yang berakar dari manajemen bisnis/ekonomi. Dari beberapa pendapat di atas maka menajemen pendidikan dapat didefinisikan sebagai implementasi universalitas fungsi-fungsi manajemen (planning,organizing, actuating dan controlling) terhadap komponenkomponen pendidikan seperti pendidik/guru, kurikulum, siswa, sarana prasarana dan lain sebagainya. Manajemen pendidikan subtansinya adalah kerjasama minimal dilakukan oleh dua orang atau lebih dalam sebuah sistem pendidikan.

\section{Lembaga Pendidikan Anak}

Lembaga pendidikan anak adalah sebuah sistem atau lembaga pendidikan untuk membantu pertumbuhan dan perkembangan jasmani dan rohani siswa di luar lingkungan keluarga dari usia 0-8 tahun (Hibana;2002; 2-3). Hammer (2001) menyatakan bahwa pendidikan anak usia dini adalah pendidikan yang diperuntukkan bagi anak pada umur 9 sampai 10 tahun. Sedangkan Ricon dan Cameron (2011) keduanya menyatakan bahwa pendidikan anak usia dini adalah pendidikan yang diperutukkan untuk anak antara 5-14 tahun. Menurut UU No 20 Tahun 2003 pendidikan anak usia dini adalah pendidikan yang diselenggarkan sebelum jenjang pendidikan dasar yang dapat berbentuk TK atau RA, kelompok bermain serta taman penitipan anak. Kemudian Hibana juga memberikan penjelasan yang sama tentang bentuk pendidikan anak yang dapat terdiri dari beberapa bentuk seperti play group, Taman kanak-kanak, Taman kanak-kanak Qur'an, pusat penitipan anak. Dari definisi di atas maka dapat dikatakan bahwa lembaga pendidikan anak adalah sistem pendidikan sebelum pendidikan dasar yang dapat terdiri dari berbagai macam bentuk baik yang dikelola pemerintah atau masyarakat.

Beberapa lembaga pendidikan anak sebagaimana disebutkan di atas yang lebih dikenal oleh masyarakat adalah TK dan Play group/taman bermain. Walaupun belum semua SD mensyaratkan calon siswanya tamat dari TK namun sebagian besar orang tua sekarang telah memasukkan anaknya pada play group dan TK. 


\section{Urgensi Manajemen Pendidik Lembaga Pendidikan Anak}

Siswa anak usia dini memiliki karakter atau cirri khas, baik secara fisik maupun mental. Oleh karena itu strategi dan metode pembelajaran yang diterapkan untuk siswa usia dini perlu disesuaikan dengan kekhasan yang dimiliki oleh siswa. Strategi dan metode yang diterapkan oleh guru akan sangat berpengaruh terhadap keberhasilan proses pembelajaran anak. Penggunaan metode pembelajaran yang tepat dan sesuai dengan karakter anak akan dapat memfasilitasi perkembangan berbagai potensi dan kemampuan anak secara optimal serta tumbuhnya sikap dan perilaku positif bagi anak.

Karakter khas yang dimiliki siswa usia dini berimplikasi pada karakter yang khas pula pada program pembelajaran termasuk pada proses pembelajaranya. Menurut Cameron $(2001$; 97) juga Hibana (2002; 29) beberapa karakter khas lembaga pendidikan anak yaitu: guru harus selalu cenderung menunjukkan kecerian, materi pembelajaran yang terintegrasi, metode pembelajaran bersifat rekreatif, desain pembelajaran yang lebih meriah dan menantang anak untuk berekplorasi serta sistem evaluasi yang bersifat alamiah. Ciri khas dari proses pembelajaran yang ada di lembaga pendidikan anak usia dini menuntut seorang guru yang mampu untuk melaksanakan tugasnya pada lembaga yang bersangkutan secara professional.

Untuk mendapatkan guru atau pendidik professional lembaga pendidikan anak mutlak dibutuhkan manajemen. Manajemen pendidik lembaga pendidikan anak bertujuan untuk mengupayakan dan mengatur keberadaan guru sebaik-baiknya, sehingga mereka mampu mengembangkan potensi yang dimilikinya dan pada giliranya mampu menjadi guru professional. Tenaga pendidik/guru professional tentunya sebagai hasil dari manajemen professional pula. Guru professional diharapkan dapat membantu mengembangkan seluruh potensi yang dimiliki oleh siswa.

\section{E. Manajemen Tenaga Pendidik Lembaga Pendidikan Anak}

Lazimnya sebuah manajemen maka proses manajemen pasti dilakukan dengan beberapa langkah yang pasti dan mantap. Lembaga pendidikan anak juga harus melakukan beberapa langkah atau fungsi manajemen yang disesuaikan dengan keadaan lembaga atau komponen yang bersangkutan. Beberapa langkah tersebut yaitu: 
1. Perencanaan

Perencanaan berarti persiapan menyususn sebuah keputusan atau kebijakan. Nawawi $(1985 ; 23)$ mengatakan bahwa perencanaan pada dasarnya adalah persiapan yang berupa langkah-langkah penyelesaian suatu masalah atau pelaksanaan suatu pekerjaan yang terarah pada pencapaian tujuan tertentu.

Perencanaan guru dalam lembaga pendidikan anak adalah sebuah aktivitas yang banyak terkait dengan kegiatan menetapkan kebutuhan guru dengan mempertimbangkan jumlah dan spesifikasi guru. Perencanaan guru harus selalu mempertimbangkan visi, misi dan tujuan dari lembaga pendidikan anak yang bersangkutan. Apabila telah diketahui dan direncanakan secara pasti mengenai jumlah dan spesifikasi guru yang akan dibutuhkan maka dapat segera dilakukan pengadaan guru.

2. Pengadaan guru

Pengadaan guru adalah aktivitas untuk mendapatkan guru baru sesuai dengan formasi dan spesifikasi yang telah ditentukan dalam perencanaan. Pengadaaan guru lembaga pendidikan anak swasta dapat dilakukan dengan dua cara yaitu pihak lembaga mengajukan guru DPK ke pemerintah serta dengan cara lembaga yang bersangkutan melakukan pengadaan secara mandiri untuk diangkat sebagai guru swasta.

Pengadaan guru lembaga pendidikan anak merupakan aktivitas penting yang dapat mempengaruhi efektivitas dan efesiensi organisasi. Oleh karena itu sejumlah aktivitas yang terkait dengan pengadaan guru seperti pengumuman kebutuhan, proses seleksi dan lainnya perlu memikirkan dan mengadakan persyaratan yang ketat baik menyangkut kompetensi akademik maupun yang terkait dengan sikap, minat dan loyalitas terhadap profesi serta lemabaga atau organisasi tempat bekerja. Kompetensi akademik yang baik tidak akan banyak menunjang kemajuan organisasi atau lembaga tempat bekerja tanpa didukung dengan minat dan loyalitas yang tinggi pada lembaga tempat bekerja, bahkan cenderung membuat kemunduran.

Seberat apapun keaadaanya lembaga pendidikan anak harus memulai penseleksian berdasarkan bertimbangan manajemen professional sebagaimana digambarkan di atas. Beberapa pertimbangan tidak professional seperti kekerabatan dan 
pertemanan harus segera dikikis habis sehingga pada gilirannya dapat memperoleh guru sesuai dengan kualifikasi dan kompetensi yang diharapkan. Sejalan dengan statement di atas adalah pendapat dari Supriadi (2005:176) dalam Sismanto (2011) menyatakan bahwa tenaga pendidik PAUD semestinya disiapkan secara professional, dimana seorang professional paling tidak mempunyai 3 unsur utama yaitu pendidikan yang memadai, disiapkan secara khusus melalui lembaga pendidikan dengan kualifikasi tertentu, keahliahan dalam bidangnya dan komitmen dalam menjalankan tugasnya.

3. Pengembangan kompetensi guru

Pengembangan kompetensi guru mutlak dibutuhkan, sebab kemajuan zaman selalu menuntut perkembangan yang begitu cepat. Kemajuan yang begitu cepat tersebut berimplikasi pada perkembangan kebutuhan siswa yang selalu berubah dan berkembang selaras dengan kemajuan dan perubahan tersebut. Pengembangan kompetensi guru harus selalu diselaraskan degan kegiatan yang terkait dengan peningkatan pengetahuan, keterampilan dan etos kerja guru dengan tujuan agar mereka betah bekerja dan semakin sempurna dalam menyelesaikan tugasnya (Wijayanti:2005). Dalam bahasa yang berbeda pengembangan kompetensi dapat diarahkan kepada peningkatan dan pengembangan guru menjadi guru professional sesuai dengan UU No 14 Tahun 2005 tentang guru dan dosen.

Sertifikasi guru yang telah dilaksanakan sejak tahun 2006 lalu telah banyak meningkatkan kompetensi guru sehingga menjadi guru professional. Baik guru berstatus negeri maupun swasta diakui sama menjadi guru professional setelah mereka dievaluasi dengan instrument tertentu dan dibuktikan dengan ijzah sertifikat. Tetapi kelulusan dari sertifikasi tersebut tidak selalu menjamin guru akan tidak menurun atau berkurang kompetensinya karena zaman yang selalu berubah sebagaimana yang disebutkan di atas. Oleh Karena itu, bentuk-bentuk pengembangan kompentensi guru masih sangat diperlukan baik kepada guru yang telah lulus sertifikasi apalagi yang belum lulus. Pengembangan dapat dilakukan melalui kesempatan studi lanjut, penataran , seminar, pelatihan, diklat, menulis, meneliti, penciptaan alat dan media pembelajaran dan kegiatan lainya yang mengarah kepada peningkatan kompetensi guru sehingga layak disebut guru 
professional. Meneliti dan menulis sangat perlu digalakkan, karena sebagian besar guru lembaga pendidikan anak lemah dalam kedua hal tersebut. Maka imbauan pemerintah agar semua guru yang telah bersertifikasi untuk melakukan PTK sangat perlu untuk diapresiasi dan dilaksanakan. Beberapa komponen yang perlu mendapat perhatian serius terkait dengan upaya pengembangan kompetensi guru adalah:

a. Status guru

Rendahnya kemampuan lembaga pendidikan anak menjadi penghambat pengelolaan terhadap status guru. Banyak guru lembaga pendidikan anak yang belum mempunyai status terhadap profesi yang dijalaninya. Untuk mendapatkan guru professional perlu ditempuh pengangkatan status guru secara bertahap. Guru yang baru masuk/baru diberikan kedudukan sebagai calon guru selama periode tertentu. Setelah dianggap mempunyai kompetensi sebagai guru melalui evaluasi tertentu yang dilakukan dapat diangkat menjadi guru kontrak atau guru tetap lembaga yang bersangkutan. Guru kontrak atau guru tetap bisa menjadi pilihan bagi guru yang bersangkutan sehingga dirinya bisa memilih status tersebut sesuai dengan kemauanya.

Terhadap status guru yang baru diangkat perlu disosialisasikan kepada semua stakeholder yang ada di lembaga anak bersangkutan. Guru baru perlu diberikan perjanjian yang jelas terhadap tugas dan wewenangnya (clear job description) sebagai seorang pendidik, termasuk juga hak-hak yang didapat ketika guru tersebut melakukan kewajibanya. Sehingga guru baru akan mengerti secara jelas akan semua hak dan kewajiban yang harus dilakukan

Usaha di atas dilakukan untuk mendapatkan guru lembaga pendidikan anak professional. Pengangkatan bertahap ini diharapkan lembaga tidak tertipu dengan kompetensi guru yang ditunjukkan pada waktu recruitment. Kompetensi guru harus dibuktikan dengan kerja nyata sebagai guru professional selama periode tertentu.

b. Kesejahteraan guru

Kesejahteraan guru telah menjadi pembahasan yang begitu luas. Idealnya kesejahteraan guru harus selalu dikaitkan dengan profesionalisme kerja mereka. Program sertifikasi guru yang 
telah dilaksanakan selama lebih kurang 3 tahun ini sangat jelas telah meningkatkan kesejahteraan guru baik guru negeri ataupun swasta. Kesejahteraan guru diharapkan dapat meningkatkan kompetensi dan kewibawaan sebagai seorang pendidik.

Terlepas dari sertifikasi guru yang masih banyak kekurangan di sana sini dan diharapkan masih terus berlanjut, lembaga pendidikan anak harus mengupayakan beberapa langkah terkait dengan upaya meningkatkan kesejahteraan guru yaitu;

1. Peningkatan gaji sesuai dengan golongan

2. Pemberian tunjangan fungsional

3. Pemberian insentif terhadap guru berprestasi

Langkah pertama dan kedua sudah lazim dilakukan, terutama untuk pegawai negeri. Untuk guru swasta langkah ini perlu dilakukan dengan mempertimbangkan beban tugas yang diberikan kepada guru yang bersangkutan. Artinya lembaga pendidikan anak swasta harus membuat mekanisme sistem penggajian layaknya pegawai negeri baik pada system penggajian yang berjenjang dan system tunjangan fungsional sesuai dengan jabatan yang guru sandang di lembaga pendidikan yang bersangkutan. Tentunya mekanisme penggajian dan pemberian tunjangan tersebut harus disesuaikan dengan kemampuan lembaga yang bersangkutan.

Kemudian, pemberian insentif kepada guru berprestasi perlu dilakukan. Insentif yang dimaksud tidak harus berwujud sejumlah uang yang melekat di gaji atau tunjangan. Tetapi insentif tersebut dapat berupa kemudahan untuk studi lanjut, kemudahan anggota keluarga untuk mengakses pendidikan, promosi jabatan dan bentuk lainya.

Jika langkah-langkah di atas dapat dilakukan maka guru akan termotivasi dan tertantang untuk menjadi guru profesional yang berprestasi di dalam institusinya. Dalam lembaga pendidikan bersangkutan akan terjadi kompetisi untuk berprestasi sehingga pada tahap berikutnya akan meningkatkan kualitas lembaganya. Perasaan senioritas dan yunioritas akan berkurang, karena bisa jadi pendapatan mereka berimbang, atau bahkan lebih tinggi dari seniornya. Hal ini akan sangat 
tergantung dari profesionalisme dan prestasi kerja yang mereka lakukan bukan semata-mata dari golongan yang dimiliki.

4. Pemberhentian guru

Pemberhentian guru adalah pemutusan hubungan kerja terhadap guru. Pemberhentian guru dapat dilakukan karena beberapa hal yaitu; pemberhentian karena inisiatif pribadi dan pemberhentian karena dari lembaga. Alasan pemutusan kerja dapat berupa; telah habis masa kerja (terlalu tua), pindah, melanggar tata tertib atau sebab lainya. Pemberhentian secara professional mesti berdasarkan pada evaluasi kinerja yang telah dilakukan guru pada periode tertentu, sehingga memunculkan untuk meneruskan atau menghentikan pekerjaanya. Idealnya evaluasi terhadap kinerja guru selalu dilakukan pada periode tertentu untuk mengetahui tingkat kinerja yang telah dilakukan oleh guru, semisal satu semester ataupun satu tahun sekali.

Lembaga pendidikan anak swasta perlu dan berani melakukan pemutusan hubungan kerja yang disebabkan karena seorang guru tidak lagi mempunyai kompetensi yang diinginkan. Pemutusan hubungan kerja dengan alasan seperti ini harus berani dilakukan, meskipun guru tersebut berstatus sebagai guru tetap lembaga ataupun guru negeri. Hal ini dilakukan untuk menjaga situasi ideal dalam lembaga yang bersangkutan.

\section{F. Kesimpulan}

Manajemen pendidik lembaga pendidikan anak adalah bagian dari manajemen pendidikan yang berimplikasi luas terhadap kualitas organisasi maupun output siswanya. Lembaga pendidikan anak adalah sebagai organisasi yang berkompeten dalam membantu perkembangan jasmani dan mental anak pada usia dini dengan berbagai macam bentuk dan tingkatnya dibawah pendidikan dasar. Salah satu komponen pendidikan yang mutlak membutuhkan manajemen professional adalah guru, sebab guru adalah salah satu komponen yang sangat bisa mempengaruhi prestasi siswa dan efektivitas organisasi.

Beberapa langkah yang dapat dilakukan dalam manajemen pendidik lembaga pendidikan anak adalah melalui perencanaan yang matang sampai tahap evaluasi dan pemutusan hubungan kerja (PHK). Pada tahap perencanaan perlu diciptakan syarat-syarat yang ketat 
untuk guru baru yang akan mengisi formasi yang ada. Pada tahap pelaksanaan perlu penciptaan kondisi organisasi yang kondusif dengan memperhatikan status dan kesejahteraan guru, Pada tahap evaluasi perlu berani melakukan pemutusan hubungan kerja terhadap guru yang tidak memenuhi kualifikasi yang dibutuhkan dalam lembaga yang bersangkutan. 


\section{Daftar Pustaka}

Anton E.Khaton (2012) Pembelajaran Agama belum sentub ranab kebidupan, kolom, Harian Kedaulatan Rakyat, Sabtu 7 Januari

Cameron, Lynne (2001) Teaching Language To Young Learners, England, Cambridge University press

Dedi Supriadi (2005) Pengelolaan Pendidikan, Bandung;UPI Bandung.

Dilema Perkembangan PAUD di Indonesia, www.kemendikbud.go.id

Fahri Hidayat (2012) Optimalisasi Pendidikan Agama Islam dalam Membangun

Akblak Mulia, kolom, Harian Kedaulatan Rakyat, Sabtu 7 Januari

Harmer, Jeremy (2001). The Practice of English Language Teaching, third edition completely revised and updated, England, Logman.

Hadari Nawawi (1985) Administrasi Pendidikan, Jakarta, Gunung Agung

Hartatai Sukirman (2000) Administrasi dan Supervisi Pendidikan, Yogyakarta: FIP UNY

Hibana S Rahman (2002) Konsep Dasar Pendidikan Anak Usia Dini, Yogyakarta; PGTKI Press

Ibrahim Bafadal (2003) Dasar-dasar Manajemen dan Supervisi Taman Kanakkanak, Malang, UN Malang Press.

Imam soepardi (1998) Dasar-dasar Administrasi Pendidikan, Jakarta;Depdikbud

Made Pidarta (1986) Manajemen Pendidikan Indonesia, Jakarta; Bina Aksara

Ngalim Purwanto (2005) Administrasi dan Supervisi Pendidikan, Bandung; Remaja Rosda Karya

Satyagraha (2005) Beberapa isu Dalam Manajemen Pendidikan, http//,www. depdiknas, accesed on 21 Januari 2009

Wiwik Wijayanti (2005) Pengelolaan Pendidikan di TK Kreatif Primagama Kota Yogyakarta, Yogyakarta; Tesis PPS UNY. 